\title{
MENINGKATKAN PERKEMBANGAN BAHASA ANAK USIA DINI DENGAN METODE BERCERITA
}

\author{
Eka Rizki Amalia \\ ekarizkiamalia2104@gmail.com \\ Amalia Rahmawati \\ amaliarahmawati649@gmail.com \\ Salma Farida \\ salmafas24@gmail.com \\ Institut Pesantren KH. Abdul Chalim (IKHAC), Mojokerto
}

\begin{abstract}
Children's language develops from easy to complex. The development of children's language is a combination of social interaction, emotional development, intellectual ability, and physical and motoric development. Early education has an important role in developing children's potential. The teacher must use methods that are in accordance with the children's learning patterns. Every child has their own needs and effective learning patterns. The needs and patterns of children's learning are a priority that must be fulfilled optimally. Therefore, teachers must be able to sort out what methods are effective for developing language in children. This paper discusses language development in early childhood with the storytelling method.
\end{abstract}

Keywords: children's language development, method of storytelling.

\begin{abstract}
Abstrak: Bahasa anak berkembang dari yang mudah menuju yang rumit. Perkembangan bahasa anak merupakan perpaduan antara interaksi sosial, perkembangan emosi, kemampuan intelektual, dan perkembangan fisik maupun motoriknya. Pendidikan awal memiliki peran yang penting dalam mengembangkan potensi anak. Guru harus menggunakan metode yang sesuai dengan pola belajar anak. Setiap anak memiliki kebutuhan dan pola belajar efektifnya masing-masing. Kebutuhan dan pola belajar anak merupakan sebuah prioritas yang harus terpenuhi dengan optimal. Oleh karena itu, guru harus dapat memilah metode apa yang efektif untuk mengembangkan bahasa pada anak. Makalah ini membahas tentang perkembangan bahasa pada anak usia dini dengan metode bercerita.
\end{abstract}

Kata kunci: perkembangan bahasa anak, metode bercerita.

Latar Belakang
Masa kanak-kanak adalah masa yang paling tepat
untuk mengembangkan bahasa karena masa kanak-kanak berada dalam fase pertumbuhan dan perkembangan yang paling pesat. Masa kanakkanak ini disebut dengan istilah The Golden Age, yaitu masa keemasan. Pada masa ini berbagai potensi yang ada dalam diri manusia berkembang dengan pesat. Dimana perkembangan fisik, motorik, intelektual, 
emosional, bahasa dan sosial berlangsung dengan cepat. Masa kanakkanak ini juga merupakan masa yang menuntut perhatian ekstra. Segala kelebihan atau keistimewaan yang dimiliki pada masa ini tidak dapat terulang untuk kedua kalinya. Itulah sebabnya masa kanak-kanak ini dikatakan sebagai masa penentu bagi kehidupan selanjutnya.

Maria Montessori dalam Britton (1992:13), seorang tokoh pendidikan anak usia dini yang terkenal, menyatakan bahwa pada rentang usia lahir sampai usia 6 tahun anak mengalami masa keemasan yang merupakan masa dimana anak mulai peka/sensitif menerima berbagai stimulus. Selama masa periode sensitif inilah, anak dengan mudah menerima stimulus-stimulus dari lingkungannya. Menurut Hurlock dalam Alex Sobur (2003:133), perkembangan awal lebih penting daripada perkembangan selanjutnya, karena dasar awal sangat dipengaruhi oleh belajar dan pengalaman. Perkembangan bahasa untuk anak usia dini meliputi empat pengembangan yaitu menyimak, berbicara, membaca dan menulis. Pengembangan tersebut harus dilakukan seimbang agar memperoleh perkembangan yang optimal.

Sejalan dengan pertumbuhan dan perkembangan anak, perbendaharaan bahasa mereka juga meningkat dalam kapasitas, keluasan dan kerumitan. Anak-anak secara bertahap beralih dari melakukan ungkapan menjadi melakukan ungkapan dengan berkomunikasi, yang juga beralih dari komunikasi melalui gerakan menjadi tuturan. Anak usia dini pada umumnya telah mampu mengembangkan keterampilan berbicara melalui percakapan kepada orang lain. Mereka dapat mengaplikasikan bahasa dengan beberapa cara seperti bertanya, berdialog dan bernyanyi. Sejak usia sekitar 2 tahun anak-anak mulai menunjukkan minat untuk mengucapkan nama benda, nama warna, nama hewan, dan namanama lainnya yang menarik perhatiannya. Minat tersebut terus berkembang seiring dengan bertambah usia dan membuktikan bertambahnya perbendaharaan kata. Dengan banyaknya kosa kata yang di 
miliki oleh anak, anak mampu berkomunikasi dengan baik di lingkungannya yang lebih luas.

Perkembangan adalah suatu pola perubahan dimana anak belajar menguasai tingkat yang lebih kompleks dari berbagai aspek. Salah satu aspek penting dalam perkembangan anak adalah aspek perkembangan bahasa. Menurut Vygotsky dalam Ahmad Susanto (2012: 73), menyatakan bahwa bahasa merupakan media untuk mengungkapkan ide dan bertanya, bahasa juga menciptakan konsep dalam kategori-kategori berpikir. Selain itu bahasa juga merupakan sarana dalam berkomunikasi yang sangat penting dalam kehidupan manusia, karena di samping berfungsi sebagai media untuk menyatakan pikiran dan perasaan kepada orang lain juga sekaligus sebagai media untuk memahami perasaan dan pikiran orang lain.

Ada dua kategori dalam keterampilan berbahasa, yakni keterampilan berbahasa reseptif dan keterampilan berbahasa produktif. Keterampilan berbahasa reseptif adalah keterampilan bahasa yang diaplikasikan untuk memahami sesuatu yang disampaikan melalui bahasa lisan dan tulisan. Adapun yang termasuk bahasa reseptif adalah kegiatan menyimak dan membaca. Sedangkan, Keterampilan berbahasa produktif adalah keterampilan bahasa yang diaplikasikan untuk menyampaikan informasi baik secara tertulis maupun lisan. Adapun yang termasuk bahasa produktif adalah kegiatan menulis dan berbicara.

Keterampilan bahasa anak khususnya pada kategori reseptif yaitu menerima bahasa, pada tingkat perkembangan yakni menyimak perkataan orang lain dan memahami cerita dengan mendengarkan guru atau teman berbicara, mendengarkan cerita sederhana, melukiskan kembali isi cerita secara sederhana, dan menyebutkan tokoh-tokoh didalam cerita. Namun, hal tersebut masih belum tercapai dengan baik karena kenyataannya anak masih banyak yang ramai dikelas saat pembelajaran berlangsung, tidak mendengarkan guru yang sedang berbicara didepan, suka berebut mainan dengan teman sebayanya, tidak fokus, dan anak pun kesulitan untuk 
melukiskan kembali isi cerita. Berdasarkan permasalahan yang ada, dapat disimpulkan bahwa masalah yang dihadapi anak terdapat pada keterampilan mendengarkan atau menyimak yang rendah. Padahal keterampilan mendengarkan pun perlu diajarkan sebagai bagian dari perkembangan bahasa (Severe 2003: 30).

Upaya untuk meningkatkan keterampilan mendengarkan pada anak bisa di lakukan dengan cara kegiatan, mendengarkan radio, mendengarkan audio cerita untuk anak, mendengarkan lagu-lagu anak, bernyanyi, pesan berantai, menirukan suara, menebak suara, menjawab pertanyaan, dan lain sebagainya. Metode pembelajaran yang sesuai dengan pendidikan anak usia dini adalah metode bercerita, bercakapcakap, melakukan tanya jawab, melakukan wisata edukasi, sosiodrama. (Depdiknas 2004:18). Dari berbagai metode yang disebutkan di atas, penggunaan metode bercerita inilah yang akhirnya dipilih guna membantu siswa dalam mencapai tingkat pencapaian perkembangan penerimaan bahasa dan pengungkapan bahasa dalam hal ini penggunaan metode bercerita ini dengan : 1) menyimak perkataan orang lain, 2) memahami cerita dan menjawab pertanyaan sederhana, dan 3) menceritakan kembali cerita/dongeng yang pernah didengar (Moeslihatoen, 2004: 168).

Penerapan teknik bercerita ini diharapkan dapat mengatasi perbedaan minat belajar siswa. Penyajian teknik bercerita yang baik dapat menumbuhkan imajinasi dan mendorong kreativitas siswa dalam mengangkat pesan atau informasi yang disampaikan. Selain itu, melalui cerita pada saat anak mendengarkan dan mengikuti jalan cerita, pada saat itu juga emosi, fantasi, maupun imajinasi anak-anak menjadi aktif. Selain itu, dunia anak-anak identik dengan dunia tanpa batas, dalam artian apa yang mereka dengar, lihat dan rasakan akan mempengaruhi daya pikir mereka dan itu akan berbekas didalam pikiran mereka dalam waktu yang relatif lama. Sehingga dapat disimpulkan bahwa pembelajaran melalui metode bercerita merupakan sarana yang efektif untuk mendidik dan mengajari anak tanpa adanya kesan menggurui. 
Berdasarkan latar belakang di atas, makalah ini bertujuan untuk memberikan kita pemahaman tentang metode dalam mengembangkan bahasa pada anak. Kita akan mengetahui secara lebih spesifik metode apa yang efektif dan sesuai dengan tipe anak. Yang kita terapkan disini adalah metode bercerita. Dengan metode bercerita akan membantu perkembangan bahasa pada anak karena melalui metode bercerita indra pendengaran anak dapat berfungsi dengan baik dalam membantu kemampuan anak bicara, dan bertambahlah perbendaharaan kosa-kata anak. Dengan bertambahnya perbendaharaan kosa-kata, anak akan memiliki kemampuan dan keberanian untuk berkomunikasi kepada orang lain, sehingga anak akan terlatih dalam menata kalimat sesuai tahap perkembangannya. Penelitian ini akan membahas bagaimana metode bercerita dalam perkembangan bahasa Anak Usia Dini.

\section{Kajian Teori}

\section{Konsep Bahasa AUD}

Menurut Jahja, (2011:53) bahasa merupakan media untuk berkomunikasi. Dalam artian mencakup semua cara untuk berkomunikasi. Untuk mengungkapkannya seperti dengan menggunakan lisan, tulisan, isyarat, dan ekspresi wajah. Yang mana pemikiran dan emosi diungkapkan dalam bentuk simbol. Selanjutnya menurut Santrock (2007:353) bahasa adalah suatu bentuk komunikasi yang berupa lisan, tertulis atau isyarat yang berdasar pada suatu sistem dari simbol-simbol. Bahasa terdiri dari kata-kata yang digunakan berdasarkan aturan-aturannya untuk merangkai bermacam-macam variasi dan memadukannya.

Dari pendapat diatas dapat disimpulkan bahwa bahasa merupakan media yang paling efektif dalam membangun komunikasi. Tanpa adanya bahasa komunikasi tidak dapat berjalan dengan baik dan interaksi sosial pun tidak akan terjadi. Karena tanpa bahasa siapapun tidak dapat mengekspresikan diri untuk menyampaikan apa yang dirasakan kepada orang lain, tidak terkecuali pada anak-anak usia dini. Mereka juga sangat 
membutuhkan adanya bahasa untuk berkomunikasi dengan orang lain dan mengekspresikan sesuatu yang dirasakannya.

\section{Pengertian Perkembangan Bahasa}

(Simandjuntak dan Pasaribu, 1984:49) mengatakan bahwa anak mempunyai potensi untuk mengungkapkan apa yang ada di dalam pikiran dan hatinya melalui suara. Pertumbuhan suara akan membentuk bahasa. Bahasa adalah ucapan mengenai pikiran dan perasaan manusia dengan menggunakan alat bunyi yang teratur. Dengan berkembangnya bahasa pada anak akan memudahkan anak berkomunikasi dan mengutarakan apa yang ia inginkan dan ia rasakan kepada orang lain terlebih kepada teman sebaya. Oleh karena itu, perlunya guru memahami konsep dari perkembangan bahasa pada anak.

Selanjutnya, menurut Patmonodewo (2008:29) “Perkembangan bahasa pada anak secara perlahan beralih dari melakukan ekspresi suara lalu berekspresi dengan berkomunikasi, dan dari hanya berkomunikasi dengan menggunakan gerakan dan isyarat untuk menunjukkan keinginannya, berkembang menjadi komunikasi melalui tuturan yang tepat dan jelas”. Tahapan perkembangan anak yang diungkapkan melalui pikiran dan menggunakan kata-kata yang menandakan meningkatnya kemampuan dan keterampilan anak sesuai dengan tahap pengembangannya.

Berdasarkan beberapa pendapat diatas dapat disimpulkan bahwa perkembangan bahasa anak dimulai sejak bayi, yang berlandaskan pada pengalaman, kecakapan dan progres dalam berbahasa. Perkembangan bahasa merupakan media yang efektif bagi anak dalam menjalin komunikasi sosial. Dengan berkembangnya bahasa pada anak akan memudahkan anak dalam mengutarakan apa yang ia inginkan dan sampaikan kepada orang lain. Oleh karena itu, pengembangan bahasa untuk anak usia dini bertujuan agar anak mampu berkomunikasi dengan baik. 


\section{Dasar Perkembangan Bahasa AUD}

Bahasa memegang peranan penting daIam pembaharuan dan peningkatan mutu pendidikan. Khususnya di TK, fungsi bahasa ini dijelaskan dalam Depdikbud (1996) bahwa pengembangan kemampuan berbahasa anak di TK bertujuan agar anak dapat berkomunikasi dengan lingkungannya. Lingkungan yang dimaksud yaitu, lingkungan teman sebaya, maupun dengan lingkungan di sekitar tempat tinggalnya. Oleh karena itu, pemahaman tentang perkembangan bahasa anak tidak boleh dianggap sebagai hal yang biasa karena guru harus memiliki pengetahuan tentang perkembangan bahasa. Maka hal ini diharapkan menjadi dasar dan ramburambu pada saat guru melaksanakan program pembelajarannya.

Dapat disimpulkan bahwa pengertian pengembangan bahasa AUD dalam tulisan ini adalah upaya kita dalam rangka pencapaian tujuan pendidikan AUD dalam mengembangkan bahasanya. Yang lebih difokuskan pada ruang lingkup pengembangan bahasa yang tertuang dalam Satuan Pendidikan TK. Untuk dapat mencapai tujuan tersebut, pemahaman guru tentang berbahasa khususnya menyimak dan berbicara perlu dipahami secara baik.

\section{Metode Pengembangan Bahasa AUD}

Seseorang akan cakap berbicara karena mempunyai alat bicara yang sempurna dan perbendaharaan bahasa yang cukup, serta mampu mengungkapkannya. Untuk itu, sejak kecil anak perlu mengembangkan bahasanya, yakni dengan memberikan kesempatan secara alamiah. Keterampilan berbicara akan lebih mudah dikembangkan apabila anak memperoleh kesempatan mengomunikasikan sesuatu seeara alami kepada orang lain, dalam kesempatan-kesempatan yang bersifat informal (Rofi'uddin dan Zuchdi, 2001: 13). Oleh karena itu, dalam kesempatan yang bersifat formal seperti hal nya dalam kehidupan di sekolah, guru- 
guru harus kreatif menciptakan sarana dan suasana belajar bahasa yang memungkinkan terjadinya komunikasi yang alamiah.

Pembelajaran bahasa pada anak ini terdiri dari beberapa metode pembelajaran yang sesuai dengan kebutuhan anak. Teknik atau metode pembelajaran tertentu tidak dimaksudkan lebih baik dari metode lainnya. Metode pembelajaran bahasa pada anak disesuaikan dengan kebutuhan, dan kemampuan anak dalam menerimanya. Metode pembelajaran dipilih sesuai dengan tipe, kebutuhan anak dan kemungkinan metode yang paling efektif untuk diterapkan. Salah satu metode yang dapat diterapkan ialah metode bercerita dijelaskan sebagai berikut.

\section{Metode Bercerita dalam Perkembangan Bahasa AUD}

Dalam proses pembelajaran anak usia dini, ada beberapa metode yang dapat diterapkan salah satunya adalah metode bercerita. Bercerita adalah menyampaikan sesuatu yang berisi tentang suatu kejadian yang disampaikan melalui audio dan visual, dengan tujuan memberikan pengetahuan dan pesan dalam cerita tersebut (Bachir, 2005:10). Bercerita adalah menyampaikan sesuatu yang berisi perbuatan, pengalaman atau sesuatu kejadian yang nyata maupun yang rekaan belaka. Metode bercerita merupakan salah satu proses belajar bagi anak TK dengan menyajikan cerita kepada anak.

Bercerita menanamkan kemampuan berpikir dan memberikan peluang bagi anak untuk belajar menelaah kejadian-kejadian disekelilingnya. Berbagai macam cerita, diungkapan dengan perasaan yang sesuai dengan apa yang dialami, dirasakan, dan dilihat berdasarkan pengalaman yang diperoleh. (Tarigan, 1981:35) menyatakan bahwa cerita merupakan salah satu dari keterampilan berbicara yang bertujuan untuk memberikan informasi. Dengan bercerita seseorang dapat menyampaikan suatu informasi kepada orang lain. Hal ini juga berlaku pada AUD dengan adanya metode bercerita mereka secara tidak sadar pasti melakukan proses bercerita ini kepada teman sebaya, kepada keluarga, maupun kepada 
lingkungan sekitar. Kegiatan bercerita merupakan salah satu metode yang digunakan guru dalam memberikan pembelajaran agar anak memahami isi cerita yang disampaikan dengan lebih optimal. Adapun tujuan dari metode bercerita menurut Moeslichatoen (2004:170) adalah sebagai berikut :

a. Menanamkan nilai-nilai sosial, moral dan keagamaan dan memberikan informasi tentang lingkungan sekitar.

b. Agar anak mampu memahami pesan-pesan yang disampaikan melalui kegiatan bercerita.

c. Agar anak mampu mendengarkan dengan seksama terhadap apa yang disampaikan orang lain.

d. Agar anak dapat berpikir dan bertanya apabila tidak memahaminya.

e. Agar anak mampu menjawab pertanyaan yang diutarakan orang lain.

f. Agar anak mampu menceritakan dan mengekspresikan apa yang didengarnya, sehingga pesan dari isi cerita dapat disampaikan dan dipahami orang lain.

\section{Fungsi Metode Bercerita dalam Perkembangan Bahasa AUD}

Fungsi dari metode bercerita ini menurut (Tampubolon, 1991:50), "Bercerita kepada anak merupakan peranan penting karena bukan hanya menanamkan minat dan kebiasaan membaca, tetapi juga mengembangkan bahasa dan cara anak dalam berpikir”. Dengan adanya metode bercerita pendengaran anak dapat berfungsi dengan baik dan dapat membantu kemampuan anak dalam bicara. Dengan bertambahnya perbendaharaan kosa-kata pada anak, meningkatlah kemampuan anak dalam mengucapkan kata-kata, melatih anak dalam menyusun kalimat sesuai dengan tahap perkembangannya. Selanjutnya anak bisa mengeksplornya melalui bernyanyi, bersyair, ataupun menulis sehingga nantinya anak mampu membaca tulisan atau bahasa isyarat. Kemampuan tersebut adalah dampak positif dari proses menyimak dalam tahap perkembangan bahasa anak.

Tahapan perkembangan dimulai dari kemampuan mendengar, berbicara, menulis dan menyimak sesuai dengan tahap perkembangan 
anak. Setiap anak memiliki cara belajar yang berbeda-beda, untuk itu melalui bercerita guru diharapkan mampu memahami gaya belajar anak baik individual maupun secara berkelompok. Dengan mengembangkan pembelajaran terpadu dan tematik yang berpusat pada anak. Selain itu, didalam metode bercerita terdapat beberapa teknik yang dapat digunakan seperti yang dikemukakan oleh Moeslichatoen (2004:158-160) antara lain sebagai berikut :
a. Langsung membaca dari buku cerita,
b. Bercerita dengan media ilustrasi gambar dari buku,
c. Menceritakan dongeng,
d. Bercerita dengan menggunakan media papan flannel,
e. Bercerita dengan menggunakan media boneka,
f. Dramatisasi suatu cerita,
g. Bercerita sambil menggerakan jari-jari tangan.

Berdasarkan penjelasan tersebut, dari berbagai metode bercerita dapat digunakan salah satu sebagai pilihan. Hal ini bertujuan agar penggunaan metode bercerita tidak menjenuhkan anak. Dengan metode bercerita dapat menstimulasi anak tidak hanya tentang menyimak cerita, tetapi juga tentang bercerita atau berbicara. Anak belajar tentang cara berdialog dan bernarasi, sehingga anak terdorong untuk menirukannya. Hal ini dikarenakan didalam cerita terdapat negoisasi, pola perbuatan dan perkataan yang baik seperti meminta, mencegah, berjanji, mematuhi perintah, menjauhi larangan dan memuji. Dalam bercerita juga terkadang individu dapat menyesuaikannya dengan keinginannya sendiri. Pada hakikatnya berbicara sama dengan menuangkan segala perasaan. Dengan bercerita kita dapat mengungkapkan dan mengekspresikan keinginan kita.

\section{Kelebihan dan Kekurangan Metode Bercerita}

Setiap metode pasti memiliki kelebihan dan kekuranganya tersendiri. Adapun kelebihan dan kekurangan dalam menerapkan metode bercerita menurut Dhieni (2006:6-9) antara lain: 
1. Dengan menerapkan metode bercerita guru dapat menguasai kelas dengan jumlah anak yang relatif banyak,

2. Dengan metode cerita waktu yang tersedia dapat dimanfaatkan secara efektif dan efisien,

3. Dengan metode bercerita maka pengaturan kelas menjadi lebih sederhana,

4. Metode bercerita relatif tidak banyak memerlukan biaya,

5. Dengan metode ini anak-anak akan menjadi pasif, karena lebih banyak mendengarkan atau menerima penjelasan dari guru,

6. Metode ini kurang mendorong perkembangan kreativitas dan kemampuan anak untuk mengutarakan pendapatnya.

7. Daya tangkap anak didik berbeda dan masih lemah sehingga sukar memahami tujuan dari isi cerita,

8. Metode ini juga cepat menumbuhkan rasa jenuh terutama apabila penyajiannya tidak menarik dan monoton.

\section{Hubungan Antara Bahasa, Berbicara, dan Bercerita}

Bahasa (language) dan bicara (speech) adalah dua hal yang tidak dapat dilepaskan antara satu dengan yang lain, karena bahasa mencakup setiap bentuk komunikasi yang muncul akibat pikiran dan perasaan untuk menyampaikan sesuatu kepada orang lain (Hurlock, 1988). Dalam bahasa tersebut, diperlukan penggunaan tanda-tanda atau simbol ke dalam sebuah aturan bahasa yang berada dalam struktur aturan tertentu. Anak akan mengerti ungkapan seseorang karena melalui perbendaharaan kata yang disampaikan. Akan tetapi, apabila tidak memiliki sejumlah perbendaraan kata atau kosa kata yang akan digunakan sebagai komponen dalam berbicara, anak akan sulit untuk berbicara atau berkata-kata. Dengan demikian, meskipun sarana lain untuk berbicara terpenuhi, jika tidak memiliki kosakata, seseorang anak akan kesulitan dalam berkomunikasi dengan orang lain (Tarmansyah, 1966). Jadi, bahasa tidak sama dengan bicara. Pada awalnya anak belajar berbicara, agar ia dapat memenuhi 
kebutuhannya. Pemenuhan kebutuhan tersebut akan muncul pada saat anak mulai menggunakan kata-kata yang diperlukannya. Anak akan lancar berbicara jika anak sudah memiliki kesiapan berbicara. Ada dua proses yang menentukan kesiapan anak dalam berbicara. Kedua hal tersebut adalah (i). perkembangan kognitif dan (ii). perkembangan bahasa (Dworetzky,1990).

Dengan banyaknya anak menyimak cerita maka akan banyak pula perbendaharaan kosa kata yang dimiliki oleh anak. Dengan banyaknya perbendaharaan kosa kata pada anak maka anak akan dengan mudah untuk berkomunikasi dan bercerita kepada orang lain karena jika anak tidak memiliki kosa kata untuk berbicara maka akan sulit bagi anak untuk mengutarakan apa yang ia rasakan dan pikirkan. Sehingga cenderung anak ini akan berdiam diri dan sulit untuk berkomunikasi dengan orang lain. Oleh sebab itu, hubungan bahasa, berbicara dan bercerita ini sangat berkaitan dalam proses perkembangan bahasa AUD.

\section{Kesimpulan}

Berbahasa tidak dapat dipisahkan dengan berbicara dan berpikir. Secara tidak disadari, ketika orang berbicara selalu menggunakan pengetahuan bahasa dan pikirannya. Tanpa hal tersebut, ungkapan yang terlahir adalah ucapan yang berada di luar pemikirannya atau bahkan ucapan yang salah. Bentuk kesalahan dalam berbicara pada anak mempunyai latar belakang dan alasan yang tidak selalu sarna antara anak yang satu dengan anak yang lain. Hal tersebut diakibatkan oleh beberapa faktor, baik faktor dari luar dan dari dalam diri anak. Dari mana pun asalnya faktor tersebut, guru sebagai orang yang berada di lingkungan anak ketika anak disekolah hendaklah mampu dan mau menjadi pengarah, pembimbing, penyejuk, dan model bagi anak, agar mereka mampu dan terampil berbicara dengan kemampuan bahasanya. Pengembangan berbahasa pada AUD di sekolah, lebih ditujukan pada (i). Kesanggupan dalam menyampaikan pikiran kepada orang lain, (ii). Mengembangkan perbendaharaan kata, (iii). Menangkap 
pembicaraan orang lain, dan (iv). Keberanian untuk mengemukakan pendapat.

Agar pengembangan bahasa ini dapat berjalan dengan baik dan tujuan dapat tercapai, Maka guru hendaklah pandai dalam memilih teknik pembelajaran yang relatif dan sesuai untuk anak. Metode yang dapat diterapkan adalah bercerita. Dengan pemilihan metode yang tepat, diharapkan anak akan mampu berbahasa secara alamiah. Untuk itu, guru hendaklah memiliki pengetahuan tentang perkembangan bahasa anak, dan metode pengembangan bahasa anak.

\section{Daftar Pustaka}

Bachir, Bachtiar S. (2005). Pengembangan Kegiatan Bercerita di Taman Kanakkanak dan Teknik dan Prosedurnya. Jakarta: Depdiknas.

Britton, Lesley. (1992). Montessori Play and Learn. London: Vermilion.

Depdikbud. (1996). Didaktik/Metodik Umum di Taman Kanak-kanak. Depdikbud Jakarta: Dirjen Pendidikan Dasar dan Menengah.

Depdiknas. (2004). Kurikulum TK dan RA. Depdiknas Jakarta: Dirjen Pendidikan Dasar dan Menengah.

Dhieni, Nurdiana. (2006). Metode Perkembangan Bahasa. Jakarta: Universitas Terbuka.

Dworetzky, J.P. (1990). Introduction to Child development. 4 th,ed. New York: Wesk Publishing Company.

Hurlock, Elizabeth, B. (1998). Perkembangan Anak Jilid I. Jakarta: Erlangga.

Moeslihatoen. (2004). Metode Pengajaran Di Taman Kanak-kanak. Jakarta: PT. Asdi Mahasatya.

Patmonodewo, Soemiarti. (2008). Pendidikan Anak Prasekolah. Jakarta: Rineka Cipta.

Rofi'uddin, Ahmad. Zuchdi, Darmiyati. (2001). Pendidikan Bahasa dan Sastra Indonesia di Kelas Tinggi. Malang: Universitas Negeri Malang.

Santrock, J.W. (2007). Perkembangan Anak (edisi kesebelas, jilid 2). Jakarta: Erlangga.

Severe, Sal. (2003). Bagaimana Bersikap Pada Anak Agar Anak Prasekolah Anda Bersikap Baik. Jakarta: PT. Gramedia Pustaka Utama. 
Simanjuntak, B. Pasaribu. (1984). Pengantar Psikologi Perkembangan. Bandung: Tarsito.

Sobur, Alex. (2016). Psikologi Umum. Bandung: Pustaka Setia.

Sujiono, Yuliani Nurani. (2013). Konsep Dasar Pendidikan Anak Usia Dini. Jakarta.

Susanto, Ahmad. (2012). Perkembangan Anak Usia Dini. Jakarta: Kencana.

Tampubolon. (1991). Mengembangkan Minat dan Kebiasaan Membaca Pada Anak. Bandung: Angkasa.

Tarigan, Henry Guntur. (1991). Berbicara Sebagai Keterampilan Berbahasa. Bandung: Angkasa.

Tarmansyah. (1996). Gangguan Komunikasi. Jakarta: Depdikbud.

Yudrik, Jahja. (2011). Psikologi Perkembangan. Jakarta: Kencana. 